Published in final edited form as:

Methods Enzymol. 2006 ; 420: 339-361. doi:10.1016/S0076-6879(06)20016-8.

\title{
Mesenchymal Stem Cells and Tissue Engineering
}

\author{
Nicholas W. Marion and Jeremy J. Mao
}

\section{Abstract}

Mesenchymal stem cells (MSCs) have become one of the most studied stem cells, especially toward the healing of diseased and damaged tissues and organs. MSCs can be readily isolated from a number of adult tissues by means of minimally invasive approaches. MSCs are capable of self-replication to many passages and, therefore, can potentially be expanded to sufficient numbers for tissue and organ regeneration. MSCs are able to differentiate into multiple cell lineages that resemble osteoblasts, chondrocytes, myoblasts, adipocytes, and fibroblasts and express some of the key markers typical of endothelial cells, neuron-like cells, and cardiomyocytes. MSCs have been used alone for cell delivery or seeded in biomaterial scaffolds toward the healing of tissue and organ defects. After an increasing number of the "proof of concept" studies, the remaining tasks are many, such as to determine MSC interactions with host cells and signaling molecules, to investigate the interplay between MSCs and biological scaffold materials, and to apply MSCbased therapies toward clinically relevant defect models. The ultimate goal of MSC-based therapies has valid biological rationale in that clusters of MSCs differentiate to form virtually all connective tissue during development. MSC-based therapies can only be realized our improved understanding of not only their fundamental properties such as population doubling and differentiation pathways but also translational studies that use MSCs in the de novo formation and/or regeneration of diseased or damaged tissues and organs.

\section{MSCs: Definition and Therapeutic Promise}

"Mesenchymal stem cells" (MSCs) are named out of compromise. During embryonic development, mesenchyme or the embryonic mesoderm contains stem cells that differentiate into virtually all connective tissue phenotypes such as bone, cartilage, bone marrow stroma, interstitial fibrous tissue, skeletal muscle, dense fibrous tissues such as tendons and ligaments, as well as adipose tissue. In vertebrates, mesenchyme is usually abundant and contains unconnected cells in contrast to rows of tightly connected epithelial cells that derive from the ectoderm (Alberts et al., 2002). Mesenchymal-epithelial interactions are critical for both appendicular skeletogenesis and craniofacial morphogenesis (Gilbert, 2000; Mao et al., 2006). On the completion of prenatal morphogenesis, clusters of mesenchymal cells likely continue to reside in various tissues and are the logical sources of adult mesenchymal stem cells.

In the adult, the definition of a common progenitor for all connective tissues inevitably elicits controversy. Strictly speaking, mesenchyme defined as embryonic mesenchyme should not exist in the adult. Despite this textbook dilemma, it is without doubt that adult connective tissues contain progenitor cells that maintain physiologically necessary tissue turnover and, on trauma or pathological conditions, are responsible for tissue regeneration. Whereas amicable and dispassionate debate continues regarding the appropriateness of the 
term mesenchymal stem cells (MSCs), or sibling terms such as mesenchymal progenitor cells (MPCs), bone marrow progenitor cells (BMPCs), or bone marrow stromal cells $(B M S C s)$, the scientific community and health care industry demand a workable term for communication. The editors' choice of "Mesenchymal Stem Cells" as the chapter's title is yet another indication of this need.

What we now know as mesenchymal stem cells were first identified as colony-forming unit fibroblast-like cells in the 1970s (Friedenstein et al., 1970, 1976). Numerous reports since have demonstrated that bone marrow, adipose tissue, tooth pulp, etc., contain a subset of cells that not only are capable of self-replication for many passages but also can differentiate into multiple end-stage cell lineages that resemble osteoblasts, adipocytes, chondrocytes, myoblasts, etc. (Alhadlaq and Mao, 2004). Recently, bone marrow-derived cells have been shown to differentiate into nonmesenchymal lineages such as hepatic, renal, cardiac, and neural cells (Alhadlaq and Mao, 2004). MSCs have been identified in an increasing number of vertebrate species including humans (Alhadlaq and Mao, 2004).

Our understanding of MSCs has advanced tremendously because of their demonstrated and perceived therapeutic capacity (Alhadlaq and Mao, 2004; Aubin, 1998; Bianco et al., 2001; Krebsbach et al., 1999; Kuo and Tuan, 2003; Mao et al., 2006; Pittenger et al., 1999; Tuli et al., 2003). Why are MSCs perceived superior to autologous tissue grafts in the regeneration of human tissue and organs? Autologous tissue grafts often represent the current clinical "gold standard" for the reconstruction of defects resulting from trauma, chronic diseases, congenital anomalies, and tumor resection. However, autologous tissue grafting is based on the concept that a diseased or damaged tissue must be replaced by like tissue that is healthy. Thus, the key drawback of autologous tissue grafting is donor site trauma and morbidity. For example, healthy cartilage must be surgically isolated to repair arthritic cartilage. A patient who receives a bone graft harvested from his or her illiac crest for facial bone reconstruction is hospitalized for an extended stay because of donor site trauma and morbidity of the illiac crest, instead of facial surgery. Also, spare healthy tissue is scarce because of biological design during evolution. In contrast, MSC-based therapeutic approaches may circumvent the key deficiencies associated with autologous grafting procedures. First, a teaspoonful of MSC-containing aspirates can be obtained from bone marrow, or other sources, and expanded to sufficient numbers for healing large, clinically relevant defects. Second, MSCs can differentiate into multiple cell lineages, thus providing the possibility that a common cell source can heal many tissues, as opposed to the principle of harvesting healthy tissue to heal like tissue in association with autologous tissue grafting. Finally, MSCs or MSCderived cells can be seeded in biocompatible scaffolds, which can be shaped into the anatomical structure that is to be replaced by MSCs. The construct is then surgically implanted to heal the defect.

MSC-based therapies can be autologous (from self) and thus eliminate the issues of immunorejection and pathogen transmission or allogenic for potentially off-the-shelf availability. Autologous MSC-based therapies are also expected to be superior to other surgical approaches such as allogenic grafts, xenogenic grafts, or synthetic materials such as total joint replacement prosthesis. Besides the issues associated with immunorejection, pathogen transmission, wear and tear, and allergic metal reactions, the key drawback 
allogenic tissue grafts, xenogenic tissue grafts, or synthetic materials is a general deficiency of physiologically necessary remodeling that must take place over years of postsurgical ageing (Barry, 2003; Mao, 2005). For example, the general life span of a surgically successful total joint replacement is 8-10 years, far too short for arthritic patients in their $40 \mathrm{~s}, 50 \mathrm{~s}$, or even 60s. Recently, we and others have reported the tissue engineering of an entire articular condyle with both cartilage and bone layers from a single population of MSCs (Mao, 2005). The biological rationale for MSC-based total joint replacement is that clusters of MSCs initiate joint morphogenesis during embryonic development (Archer et al., 2003; Dowthwaite et al., 2003).

\section{Isolation and Expansion of MSCs}

When bone marrow content was isolated and cultured, a subset of fibroblast-like cells were observed to differentiate into osteoblasts (Friedenstein, 1995; Friedenstein et al., 1970, 1976). Numerous reports since then have shown that these fibroblast-like cells that adhere to tissue culture polystyrene are capable of not only population doubling but also differentiating into multiple cell lineages in addition to osteoblasts, such as chondrocytes, myoblasts, and adipocytes (Alhadlaq and Mao, 2004). The protocol by centrifugation in a density gradient to separate bone marrow-derived mononucleated cells from plasma and red blood cells is still widely used. The mononucleated cells can then be plated on tissue culture polystyrene with frequent changes of culture medium. Nonadherent cells such as hematopoietic cells are discarded on medium change. Some of the adherent cells are MSCs (Aubin, 1998; Caplan, 1991).

The isolation of MSCs has been recently reviewed (Alhadlaq and Mao, 2004). Bone marrow extracts contain heterogeneous cell populations. MSCs represent a small fraction of total mononucleated cells within bone marrow (Barry, 2003). Further enrichment techniques have been explored such as positive selection using cell surface markers including STRO-1, CD133 (prominin, AC133), p75LNGFR (p75, low-affinity nerve growth factor receptor), CD29, CD44, CD90, CD105, c-kit, SH2 (CD105), SH3, SH4 (CD73), CD71, CD106, CD120a, CD124, and HLA-DR (Alhadlaq and Mao, 2004; Lee et al., 2004; Pittenger et al., 1999). Flow cytometry is another helpful enrichment tool based on an array of cell surface markers. Negative selection is also helpful by the use of antibody cocktails that label bone marrow-derived cells that are not MSCs (Alhadlaq and Mao, 2004; Marion et al., 2005). For example, CD34 can be used as a specific marker for hematopoietic cells. Once the enriched bone marrow sample is placed atop the Percoll or Ficoll gradient and centrifuged, the dense cells and cell-antibody units are drawn to the bottom, leaving the desired cells atop the gradient (Marion et al., 2005). The enriched layer likely will contain a high concentration of MSCs that can be plated and expanded. An example of culture-expanded human MSCs is provided in Fig. 1A.

MSCs can undergo population doubling to a substantial number of passages, but perhaps not unlimited, although unlimited implies a process that cannot be experimentally tested. Human MSCs (hMSCs) may demonstrate an initial lag phase during expansion, but this is followed by rapid proliferation with an average population doubling time of $12-24 \mathrm{~h}$, and with some anticipated variation among donors and with aging (Spees et al., 2004). The estimated 
number of hMSCs in a $2 \mathrm{ml}$ bone marrow aspirate is between 12.5 and 35.5 billion (Spees et $a l ., 2004)$. The multipotency of hMSCs is retained up to 23 population doublings (Banfi $e t$ al., 2000), whereas no visible change in morphology of MSCs takes place until after 38 population doublings (Bruder et al., 1997). Interestingly, osteogenic differentiation of hMSCs seems to be preserved despite apparent cell senescence and slowdown in proliferation rate (Banfi et al., 2000; Bruder et al., 1997). Numerous studies have attempted to improve the culture conditions and to increase the expandability of primary MSCs. For example, fibroblast growth factor-2(FGF2) enhances the proliferation rate of primary MSCs without substantial reduction in their differentiation potential (Banfi et al., 2000; Bruder et al., 1997; Tsutsumi et al., 2001). Similar to other somatic cells, MSCs undergo telomere shortening with each cell division, which eventually results in a cessation in cell proliferation. FGF-2 delays, but does not eliminate, cell senescence (Derubeis and Cancedda, 2004; Martin et al., 1997). Although telomere shortening usually leads to the cessation of cell proliferation, telomerase can repair telomeres after each cell division, thus increasing the cell's lifespan (Derubeis and Cancedda, 2004). Immortalized MSC cell lines have been developed such as the HMPC32F (Osyczka et al., 2002). HMPC32F has been shown to possess multilineage differentiation potential toward osteogenic, chondrogenic, and adipogenic lineages, while exceeding the lifespan of normal adult human mesenchymal stem cells (Osyczka et al., 2002). This MSC cell line was created by infecting primary MSCs with the human papilloma virus Type16 with E6/E7genes within a viral vector. Immortalization was determined after multilineage differentiation for up to a year in culture and up to approximately 20 passages. Cell lines are valuable experimental tools but are not intended for clinical translation.

\section{Isolation Protocol}

\section{Human Bone Marrow-Derived MSCs}

- Ficoll-Paque-room temperature (e.g., StemCells, Inc., Vancouver, BC, Canada).

- Bone marrow sample—room temperature (e.g., AllCells, LLC, Berkeley, CA).

- $10 \mathrm{ml}$ marrow $+5 \mathrm{ml}$ DPBS $+125 \mathrm{U} / \mathrm{ml}$ heparin (total volume, $15 \mathrm{ml}$ ).

- Basal culture media (89\% DMEM-low glucose, 10\% fetal bovine serum [FBS], 1\% antibiotics).

- RosetteSep MSC enrichment cocktail (StemCells, Inc.).

- $100 \mathrm{ml}$ PBS with 2\% FBS and 1 mM EDTA.

- Transfer the bone marrow sample to a 50-ml conical tube. Add $750 \mu$ RosetteSep $(50 \mu \mathrm{l} / 1 \mathrm{ml}$ of bone marrow, $50 \mu \mathrm{l} \times 15 \mathrm{ml}=750 \mu \mathrm{l})$.

- Incubate for min at room temperature.

- Add $15 \mathrm{ml}$ of PBS 2\% FBS $1 \mathrm{mM}$ EDTA solution to bone marrow. Total volume is $30 \mathrm{ml}$.

- Add 15 ml Ficoll-Paque to two new 50-ml conical tubes. 
- Layer bone marrow solution gently on top of the Ficoll-Paque in each tube. Do not allow marrow to mix with the Ficoll-Paque.

- Centrifuge for $25 \mathrm{~min}$ at $300 \mathrm{~g}$ with brake off at room temperature.

- Remove enriched cells from Ficoll-Paque interface.

- Wash enriched cells with PBS-FBS-EDTA solution in 50-ml tube and centrifuge at $1000 \mathrm{rpm}$ for $10 \mathrm{~min}$, brake off.

- Plate cells approximately 0.5-1 million total per petri dish with basal culture media. (Now referred to as primary cultures or passage $0[\mathrm{P} 0]$ ).

- Change medium every 2 days. Remove nonadherent cells during medium changes. Some of the adherent colonies are of mesenchymal lineage.

\section{Multilineage Differentiation of MSCS}

MSCs are clearly capable of multilineage differentiation into osteoblasts, chondrocytes, myoblasts, adipocytes, etc. in ex vivo culture (Alhadlaq and Mao, 2004; Barry, 2003; Caplan, 1991; Caplan and Bruder, 2001; Derubeis and Cancedda, 2004; Gao and Caplan, 2003; Gregory et al., 2005a,b; Indrawattana et al., 2004; Pittenger et al., 1999; Sekiya et al., 2002). The differentiation of MSCs toward osteogenic, chondrogenic, and adipogenic lineages is reviewed later. For myogenic differentiation, the reader is referred to several comprehensive reviews (Bhagavati and Xu [2004]; Gang et al. [2004]; Xu et al. [2004]).

\section{Chondrogenic Differentiation}

Chondrogenic differentiation of MSCs has tremendous significance in cartilage regeneration. Cartilage has poor capacity for self-regeneration because of the scarcity of resident chondroprogenitor cells in the adult (Alberts et al., 2002; Mao, 2005). Most of the sparse cells in adult articular cartilage are mature chondrocytes engaged in matrix maintenance instead of active chondroprogenitor cells capable of proliferation and differentiation into chondrocytes (Hunziker, 2002). Recent work demonstrates that articular cartilage contains a small population of cells that possess some of the same properties as progenitor cells (Dowthwaite et al., 2003). However, the full capacity of these progenitorlike cells is yet to be explored. The clinical observation that injuries to articular cartilage beyond certain degrees fail to self-repair still serves as the rationale for exploring the healing capacity of MSCs in cartilage regeneration (Mao, 2005).

Chondrogenic Stimulants-Transforming growth factors including TGF- $\beta 1$, TGF- $\beta 2$, or TGF- $\beta 3$ have been repeatedly demonstrated to stimulate chondrogenesis of MSCs (Barry, 2003). A combination of TGF- $\beta 3$ and bone morphogenetic protein-6(BMP-6) increases cartilage matrix deposition (Sekiya et al., 2001). Cyclical exposure to TGF- $\beta$ induces a significant increase in matrix deposition compared with continuous exposure of TGF- $\beta 3$ alone,BMP-6 alone, or in combination (Sekiya et al., 2001, 2002).

Although MSCs can differentiate into chondrocyte-like cells in a 2D culture system, there is a tendency for 2D differentiated chondrocytes to dedifferentiate and/or transdifferentiate into fibroblast-like cells. Even mature chondrocytes isolated from articular cartilage have a 
tendency to dedifferentiate and/or transdifferentiate on prolonged culture in 2D (Haudenschild et al., 2001; Jakob et al., 2001). Alternatives to 2D culture of chondrocytes include approaches such as micromass culture or pellet culture, differentiating MSCs toward chondrocytes in 3D biomaterials, or self-assembly of MSCs into 3D chondrogenic structures. By centrifuging a known quantity of MSCs in the bottom of a conical tube, for example, 250,000-1.5 million cells, and using a variety of serum-free medium solutions combined with growth factor administration, hMSCs will differentiate toward the chondrogenic lineage. Chondrogenic differentiation medium is frequently high-glucose DMEM as opposed to the medium for hMSC expansion. Fetal bovine serum does not seem to be necessary for chondrogenic differentiation of MSCs. In some formulations, selected bioactive factors are added such as L-proline at $40 \mu \mathrm{g} / \mathrm{ml}$, ITS (insulin, transferring, and sodium selenite) at $1 \times$ solution, and sodium pyruvate at $100 \mu \mathrm{g} / \mathrm{ml}$. Dexamethasone at 100 $\mathrm{n} M$ and L-ascorbic acid 2-phosphate (AsAP) at $50 \mu \mathrm{g} / \mathrm{ml}$ has also been incorporated (Johnstone et al., 1998; Sekiya et al., 2001, 2002; Yoo et al., 1998).

MSCs can be differentiated into chondrocytes in 3D biocompatible scaffolds, partially to circumvent the possibility of dedifferentiation and/or trans-differentiation in extended 2D culture system. Polymeric scaffolds such as alginate, agarose, chitosan, and poly (ethylene glycol) diacrylate (PEGDA) hydrogels have been used to provide 3D environments for chondrogenic differentiation of MSCs (Alhadlaq et al., 2004; Anseth et al., 2002; Hung et al., 2003; Kim et al., 2003; Williams et al., 2003; Woodfield et al., 2006). The feasibility to polymerize biomaterials into complex anatomical structures makes several hydrogels well suited for cartilage tissue engineering. MSCs can be exposed to chondrogenic-supplemented medium, such as TGF- $\beta$ family, while encapsulated in hydrogels (Alhadlaq et al., 2004; Anseth et al., 2002; Kim et al., 2003; Williams et al., 2003). The advantage of 3D hydrogel encapsulation is that of minimizing the need to disrupt 2D monolayer culture or pellet culture before seeding cells in 3D.

Several reports have demonstrated that chondrocytes can elaborate 3D matrices and selfassemble into cartilage-like structures, sometimes when seeded on top of a biomaterial instead of within it (Klein et al., 2003; Masuda et al., 2003). Isolated chondrocytes are initially cultured on top of agarose or alginate gels to produce the cell-associated matrix, rather than encapsulated within gels, followed by additional 2D culture until cell-matrix structures reach a certain size. This represents a convenient variation of the 3D culture approach and may have therapeutic relevance in cartilage tissue engineering.

\section{Chondrogenic Differentiation Protocol: Rat MSCs}

- Rat chondrogenic medium: 89\% DMEM-low glucose, 10\% FBS, $1 \%$ antibiotic solution, supplemented with $10 \mathrm{ng} / \mathrm{ml}$ recombinant rat TGF- $\beta 1$.

- Plate rat MSCs in monolayer culture with basal medium until $80 \%$ confluent.

- Remove basal medium and continue monolayer culture with rat chondrogenic medium (previously) for an additional 2 weeks, and change medium biweekly.

- Monolayer cultures may be fixed for histological analysis or for quantification of biochemical markers using $1 \%$ Triton-X100. 


\section{Chondrogenic Differentiation Protocol: Human MSCs}

- Human chondrogenic media: 95\% DMEM-high glucose, $1 \% 1 \times$ ITS + 1 solution, $1 \%$ antibiotic, $100 \mu \mathrm{g} / \mathrm{ml}$ sodium pyruvate, $50 \mu \mathrm{g} / \mathrm{ml} \mathrm{L}$-ascorbic acid 2-phosphate (AsAP), $40 \mu \mathrm{g} / \mathrm{ml} \mathrm{L}$-proline, $0.1 \mu M$ dexamethasone, and $10 \mathrm{ng} / \mathrm{ml}$ recombinant human TGF- $\beta 3$.

- Centrifuge approximately $2.5 \times 10^{5} \mathrm{hMSCs}$ in a $15-\mathrm{ml}$ conical tube at $500 \mathrm{~g}$ for 5 $\min$ at $4^{\circ}$.

- Culture with human chondrogenic medium for at least 14 days and change medium biweekly.

- Pellets may be removed from tube by inverting and gently tapping for quantitative and histological analyses.

a. 1\% Triton-X100 may be used to disrupt cell pellets for quantitative biochemical assays such as DNA, collagen, and proteoglycans.

b. Samples may be dehydrated and embedded in paraffin before sectioning and staining for histological analysis.

Chondrogenic Differentiation Markers-A number of histological dyes provide the most convenient indication of chondrogenic differentiation of MSCs. Histological dyes are reagents sensitive to the presence of proteoglycans or sulfated glycosaminoglycans. Stains for glycosaminoglycans and proteoglycans include Safranin-O/fast green and Alcian blue. These histological dyes have been conventionally used in labeling native articular cartilage and growth plate cartilage and, therefore, are reliable markers of chondrogenic differentiation.

Chondrogenic differentiation is driven by a number of transcription factors such as the SOX family (Lefebvre et al., 2001; Ylostalo et al., 2006). SOX9 is expressed in differentiating chondrocytes; deletions of SOX9 elicit abnormal endochondral bone formation and hypoplasia of the developing bone (Lefebvre et al., 2001). SOX5 and SOX6 are expressed during chondrogenic differentiation. Biosynthesis of type II collagen and aggrecan are regulated by the expression of SOX 9 and SOX5 through their activation of COL2A1 and aggrecan genes (Lefebvre et al., 2001; Ng et al., 1997; Ylostalo et al., 2006). Furthermore, collagen genes such as COL9A1, COL9A2, COL9A3, and COL11A2 are expressed in response to the expression of SOX9 (Ylostalo et al., 2006). RT-PCR, Western blotting, in situ hybridization, and immunohistochemistry are effective approaches to identify the presence of type II collagen, type X collagen, various proteoglycans such as aggrecan, decorin, and biglycan in engineered cartilage tissue. Quantitatively, collagen and sulfated GAG contents can be measured using commercially available reagent and ELISA kits or biochemical assays. Genetic analysis such as RT-PCR aims to identify the expression of chondrogenic mRNAs such as collagen II, collagen IX, SOX 9, SOX5, SOX6, COL9A1, COL9A2, COL9A3, and COL11 because of their presence during early chondral development. Gene arrays can provide a comprehensive portrait of not only cartilage-related genes but also other genes that may be important in chondrogenesis. An example of chondrogenic differentiation of rat MSCs in monolayer is provided in Fig. 1B. 
Structural analysis is necessary to determine whether tissue-engineered cartilage has microstructural and ultrastructural characteristics as native cartilage. For instance, native chondrocyte matrix is characterized with peri-cellular matrix and interterritorial matrix (Allen and Mao, 2004; Guilak, 2000; Guilak and Mow, 2000; Poole et al., 1988, 1991). Although tissue-engineered cartilage apparently has structures similar to pericellular matrix and interterritorial matrix in a number of reports, more attention has yet to be paid to structural analysis of tissue-engineered cartilage. The reader is referred to several excellent reviews of structural properties of native and engineered cartilage (Cohen et al. [1998]; Grodzinsky et al. [2000]; Hunziker [2002]; Kerin et al. [2002]; Nesic et al. [2006]; Woodfield et al. [2002]).

Mechanical testing is necessary to ascertain that tissue-engineered cartilage has the proper mechanical properties in addition to the "right ingredients" such as type II collagen and glycosaminoglycans, as well as having the "right" structural characteristics. The reader is referred to a number of excellent reviews on the mechanical properties of native and tissueengineered cartilage (Hung et al., 2004; Hunziker, 2002; Mow et al., 1984, 1999; Troken et al., 2005).

\section{Osteogenic Differentiation}

Osteogenic differentiation was the first identified end-stage lineage of MSC differentiation (Friedenstein, 1995; Friedenstein et al., 1970, 1976). Given that bone marrow is a rich source for MSCs, it should come as no surprise that MSCs can be readily differentiated into osteoblasts. An array of genetic and matrix markers have been used to verify the osteogenic differentiation of MSCs.

Osteogenic Stimulants-Several well-explored cocktails have been shown to induce MSCs to differentiate into osteoblasts. MSCs have been shown to express alkaline phosphatase after 7-14 days of exposure to $100 \mathrm{nM}$ dexamethasone, $50 \mu \mathrm{g} / \mathrm{ml} \mathrm{L}$-ascorbic acid 2-phosphate (AsAP), and $100 \mathrm{mM} \beta$-glycerophosphate (Alhadlaq and Mao, 2003, 2005; Alhadlaq et al., 2004; Marion et al., 2005). Long-term exposure of MSCs to the formula of dexamethasone, AsAP, and $\beta$-glycerophosphate results in calcium matrix deposition and the expression of late osteogenesis markers such as bone sialoprotein, osteocalcin, and osteonectin. Dexamethasone is a glucocorticoid steroid capable of either stimulating or inhibiting osteogenic differentiation of MSCs depending on dosage (Bruder $e t$ al., 1997). High dexamethasone dose stimulates adipogenic differentiation of MSCs, whereas lower doses stimulate osteogenic differentiation (Bruder et al., 1997). The addition of AsAP further facilities osteogenic differentiation, including collagen biosynthesis, in addition to its stimulatory effects on cell proliferation (Graves, 1994a,b; Jaiswal et al., 1997). A number of studies have used ascorbic acid, the bioactive component of AsAP as an osteogenic supplement. However, ascorbic acid is somewhat unstable at $37^{\circ}$ and neutral $\mathrm{pH}$, a problem not associated with AsAP (Jaiswal et al., 1997). High doses of ascorbic acid can also be toxic to cells (Jaiswal et al., 1997). Last, $\beta$-glycerophosphate is critical to stimulate calcified matrix formation in combination with the effects of dexamethasone and AsAP (Jaiswal et al., 1997). Without $\beta$-glycerophosphate, MSC-derived osteoblasts are slow to mediate a calcium phosphate matrix (Jaiswal et al., 1997). 
Several members of bone morphogenetic proteins (BMPs) have also been shown to induce the osteogenic differentiation of MSCs, including BMP-2, BMP-6, and BMP-9(Dayoub et al., 2003; Friedman et al., 2006; Katagiri et al., 1994; Li et al., 2006; Long et al., 1995;

Rickard et al., 1994; Wang et al., 1990; Wozney, 1992). BMPs are usually supplemented in combination with dexamethasone to stimulate the osteogenic differentiation of MSCs (Rickard et al., 1994). Osteogenic differentiation of MSCs using BMP-2 is dose dependent, with measurable effects between 25-100 ng/mL (Fernando-Lecanda, 1997; Rickard et al., 1994).

\section{Osteogenic Differentiation Protocol}

- Osteogenic-supplemented medium: 89\% DMEM-low glucose, $10 \%$ fetal bovine serum, $1 \%$ antibiotics, $50 \mu \mathrm{g} / \mathrm{ml}$ AsAP, $0.1 \mu M$ dexamethasone, $100 \mathrm{~m} M \beta$ glycerophosphate.

- Plate cells approximately 10,000 cells $/ \mathrm{cm}^{2}$ in monolayer.

- Culture 14-28 days and change medium biweekly.

- Monolayer cultures can be fixed for histological analysis or quantitative biochemical assays after $1 \%$ Triton-X100 is used to disrupt cells.

- Alkaline phosphatase activity may be detected within 2 weeks, whereas other bone markers may be detected later (Alhadlaq and Mao, 2003, 2005; Alhadlaq et al., 2004; Aubin, 1998; Frank et al., 2002; Malaval et al., 1999; Marion et al., 2005; Rodan and Noda, 1991).

Osteogenic Differentiation Markers-The osteogenic differentiation of MSCs is verified by several osteogenic matrix molecules, accumulation of mineral crystals and nodules, and ultimately the regeneration of bone in vivo both ectopically, such as the dorsum of immunodeficient mice, and orthotopically, such as calvarial, axial (e.g., spinal fusion) or appendicular (e.g., segmental) defects.

Up-regulation of alkaline phosphatase activity is an early indicator for the osteogenic differentiation of MSCs and can be detected quantitatively using a commercially available kinetic kit and/or histologically using a naphthol-based chemical stain (Aubin, 1998; Frank et al., 2002; Malaval et al., 1999; Rodan and Noda, 1991). Furthermore, calcium matrix synthesis is histologically verified using either von Kossa (silver nitrate) or alizarin red stains, by means of selective binding with calcium-phosphate matrix components (Aubin, 1998; Frank et al., 2002; Malaval et al., 1999; Rodan and Noda, 1991). Immunohistochemical staining for type I collagen is helpful but nonspecific. Bone sialoprotein, osteocalcin, osteopontin, and osteonectin are late osteogenic differentiation markers and can be measured genetically using RT-PCR or proteomically using ELISA (Aubin, 1998; Malaval et al., 1999; Rodan and Noda, 1991). Immunohistochemistry with antibodies will localize matrix markers in relation to cells. An example of osteogenic differentiation of hMSCs is provided in Fig. 1C.

Tissue-engineered bone must have the appropriate structural characteristics that approximate native bone. Bone is one of the highly hierarchical structures in the body. The structure of 
cortical bone differs substantially from that of cancellous bone. A number of biomaterials have been used to simulate cortical bone and cancellous bone structures in cell-based or non-cell-based approaches (Lin et al., 2004; Taboas et al., 2003). However, given the extent of bone modeling and remodeling, whether complete maturation of tissue-engineered bone is necessary before in vivo is in question. The reader is referred to several excellent reviews of structural properties of native and engineered bone (El-Ghannam, 2005; Mauney et al., 2005; Mistry and Mikos, 2005; Wan and Longaker, 2006). Mechanical testing of tissueengineered bone is of paramount importance because bone is designed to withstand mechanical stresses as its primary function. The reader is referred to a number of excellent reviews on the mechanical properties of native and tissue-engineered bone (El-Ghannam, 2005; Mauney et al., 2005; Mistry and Mikos, 2005; Wan and Longaker, 2006).

\section{Adipogenic Differentiation}

Adipogenic differentiation of MSCs has a number of perhaps underappreciated areas of significance. First, MSC differentiation into osteoblasts and adipocytes is delicately regulated and balanced (Gregory et al., 2005). Second, our knowledge of obesity is likely improved by understanding the genetic regulation of adipogenic differentiation of MSCs. Third, adipose tissue is a key structure to restore in reconstructive and augmentative surgeries such as facial cancer reconstruction and breast cancer reconstruction. Current approaches for soft tissue reconstruction and/or augmentation suffer from shortcomings such as donor site trauma and morbidity, suboptimal volume retention, donor site morbidity, and poor biocompatibility. One of the central issues of poor healing of adipose tissue grafts is a shortage and/or premature apoptosis of adipogenic cells. MSCs self-replenish, and as demonstrated later, can readily differentiate into adipogenic cells in 2D and 3D (Pittenger $e t$ al., 1999; Stosich and Mao, 2005, 2006).

Adipogenic Stimulants-With the addition of dexamethasone (0.5 $\mu M)$, 1-methyl-3isobutylxanathine (IBMX) $(0.5 \mu \mathrm{M}-0.5 \mathrm{mM})$, and indomethacin (50-100 $\mu M)$, MSCs in monolayer culture will undergo adipogenic differentiation (Alhadlaq and Mao, 2004; Alhadlaq et al., 2005; Gregory et al., 2005; Janderova et al., 2003; Lee et al., 2006; Nakamura et al., 2003; Pittenger et al., 1999; Rosen and Spiegelman, 2000; Stosich and Mao, 2005, 2006; Ylostalo et al., 2006). Insulin is another key ingredient, for example, in adipogenic differentiating medium (dexamethasone, IBMX, indomethacin) for 2-5 days, and then to a maintenance supplement of insulin (Janderova et al., 2003; Nakamura et al., 2003). In most reports of adipogenic differentiation of MSCs, dexamethasone dose is $0.5 \mu M$ or five times higher than for osteogenic differentiation of MSCs. Adipogenic differentiation is believed to take place on cell confluence, cell-to-cell contacts, a serum-free culture, or a suspension culture in methylcellulose (Rosen and Spiegelman, 2000). The growth arrest of MSC-derived chondrocytes is crucial for the subsequent activation of adipogenic differentiation processes. IBMX is a phosphodiesterase inhibitor that blocks the conversion of cAMP to 5'AMP (Gregory et al., 2005). This causes an up-regulation of protein kinase A, which results in decreased cell proliferation and upregulation of hormone sensitive lipase (HSL). HSL has been shown to convert triacylglycerides to glycerol and free fatty acids, a known adipogenic process (Gregory et al., 2005). The activation of CCAAT/enhancer binding proteins $(\mathrm{C} / \mathrm{EBP})$ coincides with the expression of peroxisome proliferator-activated 
receptor $\gamma(\operatorname{PPAR} \gamma)$, which occurs in the presence of indomethacin, a known ligand for PPAR $\gamma$ (Rosen and Spiegelman, 2000). This early transcription factor is essential for adipogenesis because it suppresses the canonical wingless (Wint) signaling, suggesting the regulation of osteogenesis and adipogenesis by PPAR $\gamma$ expression in MSCs (Gregory et al., 2005). Positive Wnt signaling inhibits osteogenic differentiation but is required for adipogenic differentiation (Gregory et al., 2005). Therefore, a delicate balance exists in the regulation of adipogenic and osteogenic differentiation, because PPAR $\gamma$ has been reported to inhibit osteogenic differentiation of progenitor cells (Cheng et al., 2003; Khan and AbuAmer, 2003). Furthermore, loss of function for PPAR $\gamma$ or $\mathrm{C} / \mathrm{EBP}(\mathrm{C} / \mathrm{EBP} a, \mathrm{C} / \mathrm{EBP} \beta$, or $\mathrm{C} /$ $\mathrm{EBP} \gamma$ ) results in detrimental effects for adipogenesis and reduced adipocyte proliferation, as well as reduced lipid vacuole deposition (Rosen and Spiegelman, 2000).

\section{Adipogenic Differentiation Protocol}

- Human adipogenic media: 89\% DMEM-low glucose, 10\% FBS, 1\% antibiotic, 0.5 $\mu M$ dexamethasone, $0.5 \mu M$ 1-methyl-3-isobutylxanathine (IBMX), $50 \mu M$ indomethacin.

- Plate cells at approximately 20,000 cells $/ \mathrm{cm}^{2}$ or $80 \%$ confluence in monolayer.

- Continue culture in human adipogenic media for up to 28 days.

- Lipids may be visible as early as 7 days and can be viewed under phase-contrast microscope.

- Monolayer cultures can be processed for histological examination after fixation or for quantitative biochemical analysis after $1 \%$ Triton-X100 is used to disrupt cells.

Adipogenic Differentiation Markers-One of the key transcriptional factors of adipogenic differentiation of MSCs is peroxisome proliferator-activated receptor $\gamma 2$ (PPAR $\gamma 2$ ), which can be detected by RT-PCR or gene arrays. Oil Red-O staining is a convenient and commonly performed histological stain. On fixing the cultures with $10 \%$ formalin, lipid vacuoles synthesized intracellularly by MSC-derived adipogenic cells bind to Oil Red-O and stain red. Hematoxylin counterstaining may be used to visualize cell nuclei in blue. Free glycerol may be quantified by lysing the cells with $1 \%$ Triton X-100 and quantitatively analyzed with a glycerol kit. Glycerol-3-phosphate dehydrogenase (G-3-PDH) can be measured as one of the key enzymes in triglyceride synthesis (Pairault and Green, 1979). RT-PCR can be used to amplify and detect additional adipogenic gene products such as lipoprotein lipase (LPL) and the polyclonal antibody a-P2 (Pittenger et al., 1999). An example of adipogenic differentiation of hMSCs is provided in Fig. 1D.

Structural analysis is necessary to determine whether engineered adipose tissue has the appropriate microstructural characteristics as native adipose tissue. Adipose tissue is unique in the sense that lipid vacuoles are accumulated intracellularly. The extracellular matrix of adipose tissue consists of primarily interstitial fibrous tissue, nerve supplies, and vascular and lymphatic network.

Mechanical testing is necessary to ascertain that tissue-engineered adipose tissue has the proper mechanical properties in addition to the "right ingredients" such as adipocytes, 
intracellular lipid vacuoles, and vascular and lymphatic supplies. The reader is referred to a number of excellent reviews on the mechanical properties of native and tissue-engineered adipose tissue, as well as biomaterials that have been used as scaffolds for adipose tissue regeneration (Beahm et al., 2003; McKnight et al., 2002; Patel et al., 2005; Patrick, 2004; Stosich and Mao, 2006).

\section{Clinical Translation of MSC-Based Therapies}

MSC-based therapies are being translated toward clinical practice to heal defects resulting from trauma, chronic diseases, congenital anomalies, and tumor resection. Because of space limitation, it is impossible to outline all the ongoing effort on the clinical translation of MSC-based therapeutic approaches. Several examples are briefly introduced in the following.

Recent reports suggest the roles of MSCs in the repair of myocardial infarctions in rats and pigs on intracardiac injection (Shake et al., 2002). The precise mechanisms are unclear, although it has been suggested that MSCs may induce the homing of cardiomyocytes to the infarct site (Saito et al., 2003). Also proposed is MSC differentiation into cardiomyocytes and/or paracrine effects on intravenous MSC injection. Labeled MSCs are found in bone marrow and the site of myocardial infarction (Saito et al., 2003). Several clinical trials are ongoing at universities and biotechnology companies to explore the healing effects of MSCs on myocardial infarctions (Laflamme and Murry, 2005; Pittenger and Martin, 2004).

Several experiments have demonstrated that an entire articular condyle in the same shape and dimensions of a human temporomandibular joint can be grown in vivo with both cartilage and bone layers from a single population of MSCs (Mao, 2005; Mao et al., 2006). A visionary diagram of MSC-based therapies for total joint replacement is shown in Fig. 2, based on the work by ourselves and others (Alhadlaq and Mao, 2003, 2005; Alhadlaq et al., 2004). Although bone marrow is the most characterized source of MSCs at this time (Fig. 2), it is probable that MSCs needed for total joint replacement can also be isolated from adipose tissue by aspiration or lipectomy, fresh or banked human umbilical cord blood, placental tissue, or human teeth (Mao, 2005). Total joint replacement is one of the many examples of MSC-based therapies whose proof of concept has been demonstrated in recent years (Rahaman and Mao, 2005).

An emerging concept is that MSCs have trophic effects by secreting a variety of cytokines that function by both paracrine and autocrine pathways (Caplan and Dennis, 2006). The interactions between exogenously delivered growth factors and intrinsic cytokines synthesized by MSCs are one of the most complex and meritorious approaches in cell-based therapies. Our understanding of these fundamental paracrine and autocrine pathways will undoubtedly advance the more practical approaches in MSC-based tissue engineering. The trophic effects, as proposed by Caplan and Denis (2006), include local immune suppression, fibrosis inhibition, and angiogenesis enhancement. A number of translational and clinical studies in the areas of cardiac infarct, synovial joint regeneration, and stroke regeneration models may provide initial data to test the proposed trophic effects of MSCs. 


\section{Conclusions}

MSCs are somatic stem cells that can be readily isolated from several tissues in the adult and in multiple species. MSCs are capable of undergoing self-replication, up to the number of passages that are meaningful for potential healing of diseased tissues. Recently, we have obtained anecdotal data that that human MSCs isolated from the bone marrow of single donors can be expanded to sufficient numbers for encapsulating in osteochondral constructs as large as synovial joint condyles for in vivo implantation. MSCs are able to differentiate into multiple cell lineages that resemble osteoblasts, chondrocytes, myoblasts, adipocytes, and fibroblasts and express some of the key markers typical of endothelial cells, neuron-like cells, and cardiomyocytes. Whether a population of presumably MSCs used in a given study are truly MSCs is a biologically relevant question and can be tested by arrays of cell surface and/or genetic markers. On the other hand, once a functional biological tissue is engineered, it matters little whether the original population of tissue-forming cells are truly MSCs, as long as they can be readily isolated from the patient. Most native tissues, and certainly all organs, are formed by heterogeneous cell populations. It seems that both stem cell biology and tissue engineering approaches are necessary to advance our understanding of how MSCs can be used to heal diseased and damaged tissues and organs. For example, parallel experiments can explore the healing of tissue defects from purified or cloned MSCs, as well as MSCs among heterogeneous cell populations. Despite their first discovery in the mid 1970s, investigations of MSCs have only intensified in recent years. We submit that the true healing power of MSCs is yet to be realized.

\section{Acknowledgments}

We thank our colleagues whose work has been cited, and those whose work cannot be cited because of space limitation, for their highly meritorious work that has energized the process of composing this review. We are grateful to the remaining members of Tissue Engineering Laboratory for their dedication and hard work, in particular. Eduardo Moioli in our laboratory is gratefully acknowledged for his contribution of Fig. 1B, which demonstrates chondrogenic differentiation of rat MSCs in monolayer. We thank Janina Acloque, Maryann Wanner, and Richard Abbott for administrative support. Generous support from the National Institutes of Health is gratefully acknowledged, through NIH grants DE15391 and EB02332 to J. J. M., for the effort spent on composing this manuscript along with some of the experimental data presented in this manuscript from our laboratory.

\section{References}

Alberts, B.; Johnson, A.; Lewis, J.; Raff, M.; Roberts, K.; Walter, P. Molecular Biology of the Cell. Garland Science; New York, NY: 2002.

Alhadlaq A, Elisseeff JH, Hong L, Williams CG, Caplan AI, Sharma B, Kopher RA, Tomkoria S, Lennon DP, Lopez A, Mao JJ. Adult stem cell driven genesis of human-shaped articular condyle. Ann. Biomed. Eng. 2004; 32:911-923. [PubMed: 15298429]

Alhadlaq A, Mao JJ. Tissue-engineered neogenesis of human-shaped mandibular condyle from rat mesenchymal stem cells. J. Dent. Res. 2003; 82:951-956. [PubMed: 14630893]

Alhadlaq A, Mao JJ. Mesenchymal stem cells: Isolation and therapeutics. Stem Cells Dev. 2004; 13:436-448. [PubMed: 15345137]

Alhadlaq A, Mao JJ. Tissue-engineered osteochondral constructs in the shape of an articular condyle. J. Bone Joint Surg. Am. 2005; 87:936-944. [PubMed: 15866954]

Alhadlaq A, Tang M, Mao JJ. Engineered adipose tissue from human mesenchymal stem cells maintains predefined shape and dimension: Implications in soft tissue augmentation and reconstruction. Tissue Eng. 2005; 11:556-566. [PubMed: 15869434] 
Allen DM, Mao JJ. Heterogeneous nanostructural and nanoelastic properties of pericellular and interterritorial matrices of chondrocytes by atomic force microscopy. J. Struct. Biol. 2004; 145:196204. [PubMed: 14960370]

Anseth KS, Metters AT, Bryant SJ, Martens PJ, Elisseeff JH, Bowman CN. In situ forming degradable networks and their application in tissue engineering and drug delivery. J. Control Release. 2002; 78:199-209. [PubMed: 11772461]

Archer CW, Dowthwaite GP, Francis-West P. Development of synovial joints. Birth Defects Res. C. Embryo Today. 2003; 69:144-155. [PubMed: 12955858]

Aubin JE. Bone stem cells. J. Cell Biochem. Suppl. 1998; 30-31:73-82. [PubMed: 19594448]

Banfi A, Muraglia A, Dozin B, Mastrogiacomo M, Cancedda R, Quarto R. Proliferation kinetics and differentiation potential of ex vivo expanded human bone marrow stromal cells: Implications for their use in cell therapy. Exp. Hematol. 2000; 28:707-715. [PubMed: 10880757]

Barry FP. Biology and clinical applications of mesenchymal stem cells. Birth Defects Res. C. Embryo Today. 2003; 69:250-256. [PubMed: 14671778]

Beahm EK, Walton RL, Patrick CW Jr. Progress in adipose tissue construct development. Clin. Plast. Surg. 2003; 30:547-558viii. [PubMed: 14621302]

Bhagavati $\mathrm{S}, \mathrm{Xu} \mathrm{W}$. Isolation and enrichment of skeletal muscle progenitor cells from mouse bone marrow. Biochem. Biophys. Res. Commun. 2004; 318:119-124. [PubMed: 15110761]

Bianco P, Riminucci M, Gronthos S, Robey PG. Bone marrow stromal stem cells: Nature, biology, and potential applications. Stem Cells. 2001; 19:180-192. [PubMed: 11359943]

Bruder SP, Jaiswal N, Haynesworth SE. Growth kinetics, self-renewal, and the osteogenic potential of purified human mesenchymal stem cells during extensive subcultivation and following cryopreservation. J. Cell Biochem. 1997; 64:278-294. [PubMed: 9027588]

Caplan AI. Mesenchymal stem cells. J. Orthop. Res. 1991; 9:641-650. [PubMed: 1870029]

Caplan AI, Bruder SP. Mesenchymal stem cells: Building blocks for molecular medicine in the 21st century. Trends Mol. Med. 2001; 7(6):259-264. [PubMed: 11378515]

Caplan AI, Dennis JE. Mesenchymal stem cells as trophic mediators. J. Cell Biochem. 2006

Cheng SL, Shao JS, Charlton-Kachigian N, Loewy AP, Towler DA. MSX2 promotes osteogenesis and suppresses adipogenic differentiation of multipotent mesenchymal progenitors. J. Biol. Chem. 2003; 278:45969-45977. [PubMed: 12925529]

Cohen NP, Foster RJ, Mow VC. Composition and dynamics of articular cartilage: Structure, function, and maintaining healthy state. J. Orthop. Sports Phys. Ther. 1998; 28:203-215. [PubMed: 9785256]

Dayoub H, Dumont RJ, Li JZ, Dumont AS, Hankins GR, Kallmes DF, Helm GA. Human mesenchymal stem cells transduced with recombinant bone morpho-genetic protein- 9 adenovirus promote osteogenesis in rodents. Tissue Eng. 2003; 9:347-356. [PubMed: 12740097]

Derubeis AR, Cancedda R. Bone marrow stromal cells (BMSCs) in bone engineering: Limitations and recent advances. Ann. Biomed. Eng. 2004; 32:160-165. [PubMed: 14964731]

Dowthwaite GP, Flannery CR, Flannelly J, Lewthwaite JC, Archer CW, Pitsillides AA. A mechanism underlying the movement requirement for synovial joint cavitation. Matrix Biol. 2003; 22:311322. [PubMed: 12935816]

El-Ghannam A. Bone reconstruction: From bioceramics to tissue engineering. Exp. Rev. Med. Dev. 2005; 2:87-101.

Frank O, Heim M, Jakob M, Barbero A, Schafer D, Bendik I, Dick W, Heberer M, Martin I. Real-time quantitative RT-PCR analysis of human bone marrow stromal cells during osteogenic differentiation in vitro. J. Cell Biochem. 2002; 85:737-746. [PubMed: 11968014]

Friedenstein AJ. Marrow stromal fibroblasts. Calcif. Tissue Int. 1995; 56(Suppl. 1):S17. [PubMed: 7719975]

Friedenstein AJ, Chailakhjan RK, Lalykina KS. The development of fibroblast colonies in monolayer cultures of guinea-pig bone marrow and spleen cells. Cell Tissue Kinet. 1970; 3:393-403. [PubMed: 5523063]

Friedenstein AJ, Gorskaja JF, Kulagina NN. Fibroblast precursors in normal and irradiated mouse hematopoietic organs. Exp. Hematol. 1976; 4:267-274. [PubMed: 976387] 
Friedman MS, Long MW, Hankenson KD. Osteogenic differentiation of human mesenchymal stem cells is regulated by bone morphogenetic protein-6. J. Cell. Biochem. 2006; 98:538-554. [PubMed: 16317727]

Gang EJ, Jeong JA, Hong SH, Hwang SH, Kim SW, Yang IH, Ahn C, Han H, Kim H. Skeletal myogenic differentiation of mesenchymal stem cells isolated from human umbilical cord blood. Stem Cells. 2004; 22:617-624. [PubMed: 15277707]

Gao J, Caplan AI. Mescenchymal stem cells and tissue engineering for orthopaedic surgery. Chir. Organi. Mov. 2003; 3:305-316. [PubMed: 15146948]

Gilbert, SF. Developmental Biology. Sinauer Associates, Inc.; Sunderland, MA: 2000.

Graves SE, Francis MJO, Gundle R, Beresoford JN. Primary culture of human trabecular bone: Effects of L-ascorate-2-phosphate. Bone. 1994a; 15:132-133.

Graves SE, Gundle R, Francis MJO, Beresoford JN. Ascorbate increases collagen synthesis and promote differentiation in human bone derived cell cultures. Bone. 1994b; 15:133.

Gregory CA, Gunn WG, Reyes E, Smolarz AJ, Munoz J, Spees JL, Prockop DJ. How wnt signaling affects bone repair by mesenchymal stem cells from the bone marrow. Ann. N. Y. Acad. Sci. 2005a; 1049:97-106. [PubMed: 15965110]

Gregory CA, Prockop DJ, Spees JL. Non-hematopoietic bone marrow stem cells: Molecular control of expansion and differentiation. Exp. Cell Res. 2005b; 306:330-335. [PubMed: 15925588]

Grodzinsky AJ, Levenston ME, Jin M, Frank EH. Cartilage tissue remodeling in response to mechanical forces. Annu. Rev. Biomed. Eng. 2000; 2:691-713. [PubMed: 11701528]

Guilak F. The deformation behavior and viscoelastic properties of chondrocytes in articular cartilage. Biorheology. 2000; 37:27-44. [PubMed: 10912176]

Guilak F, Mow VC. The mechanical environment of the chondrocyte: A biphasic finite element model of cell-matrix interactions in articular cartilage. J. Biomech. 2000; 33:1663-1673. [PubMed: 11006391]

Haudenschild DR, McPherson JM, Tubo R, Binette F. Differential expression of multiple genes during articular chondrocyte redifferentiation. Anat. Rec. 2001; 263:91-98. [PubMed: 11331975]

Hung CT, Lima EG, Mauck RL, Takai E, LeRoux MA, Lu HH, Stark RG, Guo XE, Ateshian GA. Anatomically shaped osteochondral constructs for articular cartilage repair. J. Biomech. 2003; 36:1853-1864. [PubMed: 14614939]

Hung CT, Mauck RL, Wang CC, Lima EG, Ateshian GA. A paradigm for functional tissue engineering of articular cartilage via applied physiologic deformational loading. Ann. Biomed. Eng. 2004; 32:35-49. [PubMed: 14964720]

Hunziker EB. Articular cartilage repair: Basic science and clinical progress. A review of the current status and prospects. Osteoarthritis Cartilage. 2002; 10:432-463. [PubMed: 12056848]

Indrawattana N, Chen G, Tadokoro M, Shann LH, Ohgushi H, Tateishi T, Tanaka J, Bunyaratvej A. Growth factor combination for chondrogenic induction from human mesenchymal stell cell. Biochem. Biophys. Res. Commun. 2004; 320(3):914-919. [PubMed: 15240135]

Jaiswal N, Haynesworth SE, Caplan AI, Bruder SP. Osteogenic differentiation of purified, cultureexpanded human mesenchymal stem cells in vitro. J. Cell. Biochem. 1997; 64:295-312. [PubMed: 9027589]

Jakob M, Démarteau O, Schäfer D, Hintermann B, Dick W, Heberer M, Martin I. Specific growth factors during the expansion and redifferentiation of adult human articular chondrocytes enhance chondrogenesis and cartilaginous tissue formation in vitro. J. Cell. Biochem. 2001; 81:368-377. [PubMed: 11241676]

Janderova L, McNeil M, Murrell AN, Mynatt RL, Smith SR. Human mesenchymal stem cells as an in vitro model for human adipogenesis. Obes. Res. 2003; 11:65-74. [PubMed: 12529487]

Johnstone B, Hering TM, Caplan AI, Goldberg VM, Yoo JU. In vitro chondrogenesis of bone marrowderived mesenchymal progenitor cells. Exp. Cell. Res. 1998; 238:265-272. [PubMed: 9457080]

Katagiri T, Yamaguchi A, Komaki M, Abe E, Takahashi N, Ikeda T, Rosen V, Wozney JM, FujisawaSehara A, Suda T. Bone morphogenetic protein-2 converts the differentiation pathway of C2C12 myoblasts into the osteoblast lineage. J. Cell. Biol. 1994; 127:1755-1766. [PubMed: 7798324]

Kerin A, Patwari P, Kuettner K, Cole A, Grodzinsky A. Molecular basis of osteoarthritis: Biomechanical aspects. Cell Mol. Life Sci. 2002; 59:27-35. [PubMed: 11846029] 
Khan E, Abu-Amer Y. Activation of peroxisome proliferator-activated receptor-gamma inhibits differentiation of preosteoblasts. J. Lab. Clin. Med. 2003; 142:29-34. [PubMed: 12878983]

Kim TK, Sharma B, Williams CG, Ruffner MA, Malik A, McFarland EG, Elisseeff JH. Experimental model for cartilage tissue engineering to regenerate the zonal organization of articular cartilage. Osteoarthritis Cartilage. 2003; 11:653-664. [PubMed: 12954236]

Klein TJ, Schumacher BL, Schmidt TA, Li KW, Voegtline MS, Masuda K, Thonar EJ, Sah RL. Tissue engineering of stratified articular cartilage from chondrocyte subpopulations. Osteoarthritis Cartilage. 2003; 11:595-602. [PubMed: 12880582]

Krebsbach PH, Kuznetsov SA, Bianco P, Robey PG. Bone marrow stromal cells: Characterization and clinical application. Crit. Rev. Oral Biol. Med. 1999; 10:165-1681. [PubMed: 10759420]

Kuo CK, Tuan RS. Tissue engineering with mesenchymal stem cells. IEEE Eng. Med. Biol. Mag. 2003; 22:51-56. [PubMed: 14699936]

Laflamme MA, Murry CE. Regenerating the heart. Nat. Biotechnol. 2005; 23:845-856. [PubMed: 16003373]

Lee RH, Kim B, Choi I, Kim H, Choi HS, Suh K, Bae YC, Jung JS. Characterization and expression analysis of mesenchymal stem cells from human bone marrow and adipose tissue. Cell Physiol. Biochem. 2004; 14:311-324. [PubMed: 15319535]

Lefebvre V, Behringer RR, de Crombrugghe B. L-Sox5, Sox6 and Sox9 control essential steps of the chondrocyte differentiation pathway. Osteoarthritis Cartilage. 2001; 9(Suppl. A):S69-S75. [PubMed: 11680692]

Li C, Vepari C, Jin HJ, Kim HJ, Kaplan DL. Electrospun silk-BMP-2 scaffolds for bone tissue engineering. Biomaterials. 2006; 27:3115-3124. [PubMed: 16458961]

Lin CY, Kikuchi N, Hollister SJ. A novel method for biomaterial scaffold internal architecture design to match bone elastic properties with desired porosity. J. Biomech. 2004; 37:623-636. [PubMed: 15046991]

Long MW, Robinson JA, Ashcraft EA, Mann KG. Regulation of human bone marrow-derived osteoprogenitor cells by osteogenic growth factors. J. Clin. Invest. 1995; 95:881-887. [PubMed: 7860771]

Malaval L, Liu F, Roche P, Aubin JE. Kinetics of osteoprogenitor proliferation and osteoblast differentiation in vitro. J. Cell Biochem. 1999; 74:616-627. [PubMed: 10440931]

Mao JJ. Stem-cell-driven regeneration of synovial joints. Biol. Cell. 2005; 97:289-301. [PubMed: 15836429]

Mao JJ, Giannoble WV, Helms JA, Hollister SJ, Krebsbach PH, Longaker MT, Shi S. Craniofacial tissue engineering. J. Dent. Res. 2006 In Press.

Marion NW, Liang W, Reilly G, Day DE, Rahaman MN, Mao JJ. Borate glass supports the in vitro osteogenic differentiation of human mesenchymal stem cells. Mech. Adv. Mater. Struct. 2005; 3:239-246.

Martin I, Muraglia A, Campanile G, Cancedda R, Quarto R. Fibroblast growth factor-2 supports ex vivo expansion and maintenance of osteogenic precursors from human bone marrow. Endocrinology. 1997; 138:4456-4462. [PubMed: 9322963]

Masuda K, Sah RL, Hejna MJ, Thonar EJ. A novel two-step method for the formation of tissueengineered cartilage by mature bovine chondrocytes: The alginate- recovered-chondrocyte (ARC) method. J. Orthop. Res. 2003; 21:139-148. [PubMed: 12507591]

Mauney JR, Volloch V, Kaplan DL. Role of adult mesenchymal stem cells in bone tissue engineering applications: Current status and future prospects. Tissue Eng. 2005; 11:787-802. [PubMed: 15998219]

McKnight AL, Kugel JL, Rossman PJ, Manduca A, Hartmann LC, Ehman RL. MR elastography of breast cancer: Preliminary results. AJR Am. J. Roentgenol. 2002; 178:1411-1417. [PubMed: 12034608]

Mistry AS, Mikos AG. Tissue engineering strategies for bone regeneration. Adv. Biochem. Eng. Biotechnol. 2005; 94:1-22. [PubMed: 15915866]

Mow VC, Holmes MH, Lai WM. Fluid transport and mechanical properties of articular cartilage: A review. J. Biomech. 1984; 17:377-394. [PubMed: 6376512] 
Mow VC, Wang CC, Hung CT. The extracellular matrix, interstitial fluid and ions as a mechanical signal transducer in articular cartilage. Osteoarthritis Cartilage. 1999; 7:41-58. [PubMed: 10367014]

Nakamura T, Shiojima S, Hirai Y, Iwama T, Tsuruzoe N, Hirasawa A, Katsuma S, Tsujimoto G. Temporal gene expression changes during adipogenesis in human mesenchymal stem cells. Biochem. Biophys. Res. Commun. 2003; 303:306-312. [PubMed: 12646203]

Nesic D, Whiteside R, Brittberg M, Wendt D, Martin I, Mainil-Varlet P. Cartilage tissue engineering for degenerative joint disease. Adv. Drug Deliv. Rev. 2006; 58:300-322. [PubMed: 16574268]

Ng LJ, Wheatley S, Muscat GE, Conway-Campbell J, Bowles J, Wright E, Bell DM, Tam PP, Cheah KS, Koopman P. SOX9 binds DNA, activates transcription, and coexpresses with type II collagen during chondrogenesis in the mouse. Dev. Biol. 1997; 183:108-121. [PubMed: 9119111]

Osyczka AM, Noth U, O'Connor J, Caterson EJ, Yoon K, Danielson KG, Tuan RS. Multilineage differentiation of adult human bone marrow progenitor cells transduced with human papilloma virus type 16 E6/E7 genes. Calcif. Tissue Int. 2002; 71:447-458. [PubMed: 12232673]

Pairault J, Green H. A study of the adipose conversion of suspended 3T3 cells by using glycerophosphate dehydrogenase as differentiation marker. Proc. Natl. Acad. Sci. USA. 1979; 76:5138-5142. [PubMed: 291926]

Patel PN, Gobin AS, West JL, Patrick CW Jr. Poly(ethylene glycol) hydrogel system supports preadipocyte viability, adhesion, and proliferation. Tissue Eng. 2005; 11:1498-1505. [PubMed: 16259604]

Patrick CW. Breast tissue engineering. Annu. Rev. Biomed. Eng. 2004; 6:109-130. [PubMed: 15255764]

Pittenger MF, Mackay AM, Beck SC, Jaiswal RK, Douglas R, Mosca JD, Moorman MA, Simonetti DW, Craig S, Marshak DR. Multilineage potential of adult human mesenchymal stem cells. Science. 1999; 284:143-147. [PubMed: 10102814]

Pittenger MF, Martin BJ. Mesenchymal stem cells and their potential as cardiac therapeutics. Circ. Res. 2004; 95:9-20. [PubMed: 15242981]

Poole CA, Flint MH, Beaumont BW. Chondrons extracted from canine tibial cartilage: Preliminary report on their isolation and structure. J. Orthop. Res. 1988; 6:408-419. [PubMed: 3357089]

Poole CA, Glant TT, Schofield JR. Chondrons from articular cartilage. (IV). Immunolocalization of proteoglycan epitopes in isolated canine tibial chondrons. J. Histochem. Cytochem. 1991; 39:1175-1187. [PubMed: 1717545]

Rahaman MN, Mao JJ. Stem cell-based composite tissue constructs for regenerative medicine. Biotechnol. Bioeng. 2005; 91:261-284. [PubMed: 15929124]

Rickard DJ, Sullivan TA, Shenker BJ, Leboy PS, Kazhdan I. Induction of rapid osteoblast differentiation in rat bone marrow stromal cell cultures by dexamethasone and BMP-2. Dev. Biol. 1994; 161:218-228. [PubMed: 8293874]

Rodan GA, Noda M. Gene expression in osteoblastic cells. Crit. Rev. Eukaryot. Gene Expr. 1991; 1:85-98. [PubMed: 1802105]

Rosen ED, Spiegelman BM. Molecular regulation of adipogenesis. Annu. Rev. Cell Dev. Biol. 2000; 16:145-171. [PubMed: 11031233]

Saito T, Kuang JQ, Lin CC, Chiu RC. Transcoronary implantation of bone marrow stromal cells ameliorates cardiac function after myocardial infarction. J. Thorac. Cardiovasc. Surg. 2003; 126:114-123. [PubMed: 12878946]

Sekiya I, Colter DC, Prockop DJ. BMP-6 enhances chondrogenesis in a subpopulation of human marrow stromal cells. Biochem. Biophys. Res. Commun. 2001; 284:411-418. [PubMed: 11394894]

Sekiya I, Vuoristo JT, Larson BL, Prockop DJ. In vitro cartilage formation by human adult stem cells from bone marrow stroma defines the sequence of cellular and molecular events during chondrogenesis. Proc. Natl. Acad. Sci. USA. 2002; 99:4397-4402. [PubMed: 11917104]

Shake JG, Gruber PJ, Baumgartner WA, Senechal G, Meyers J, Redmond JM, Pittenger MF, Martin BJ. Mesenchymal stem cell implantation in a swine myocardial infarct model: Engraftment and functional effects. Ann. Thorac. Surg. 2002; 73:1919-1925. discussion 1926. [PubMed: 12078791] 
Spees JL, Gregory CA, Singh H, Tucker HA, Peister A, Lynch PJ, Hsu SC, Smith J, Prockop DJ. Internalized antigens must be removed to prepare hypoimmunogenic mesenchymal stem cells for cell and gene therapy. Mol. Ther. 2004; 9:747-756. [PubMed: 15120336]

Stosich MS, Mao JJ. Stem cell-based soft tissue grafts for plastic and reconstructive surgeries. Semin. Plast. Surg. 2005; 19:251-260.

Stosich MS, Mao JJ. Adipose tissue engineering from human mesenchymal stem cells: Clinical implication in plastic and soft tissue reconstructive surgeries. Plast. Reconstr. Surg. 2006 In Press.

Taboas JM, Maddox RD, Krebsbach PH, Hollister SJ. Indirect solid free form fabrication of local and global porous, biomimetic and composite 3D polymer- ceramic scaffolds. Biomaterials. 2003; 24:181-194. [PubMed: 12417192]

Troken, AJ.; Wan, LQ.; Marion, NW.; Mao, JJ.; Mow, VC. Properties of cartilage and meniscus.. In: Webster, JG., editor. The Wiley Encyclopedia of Medical Devices and Instrumentation. 2005.

Tsutsumi S, Shimazu A, Miyazaki K, Pan H, Koike C, Yoshida E, Takagishi K, Kato Y. Retention of multilineage differentiation potential of mesenchymal cells during proliferation in response to FGF. Biochem. Biophys. Res. Commun. 2001; 288:413-419. [PubMed: 11606058]

Tuli R, Seghatoleslami MR, Tuli S, Wang ML, Hozack WJ, Manner PA, Danielson KG, Tuan RS. A simple, high-yield method for obtaining multipotential mesenchymal progenitor cells from trabecular bone. Mol. Biotechnol. 2003; 23:37-49. [PubMed: 12611268]

Wan N, Longaker MT. Craniofacial bone tissue engineering. Dent. Clin. North Am. 2006; 50:175190. [PubMed: 16530056]

Wang EA, Rosen V, D'Alessandro JS, Bauduy M, Cordes P, Harada T, Israel DI, Hewick RM, Kerns KM, LaPan P. Recombinant human bone morphogenetic protein induces bone formation. Proc. Natl. Acad. Sci. USA. 1990; 87:2220-2224. [PubMed: 2315314]

Williams CG, Kim TK, Taboas A, Malik A, Manson P, Elisseeff J. In vitro chondrogenesis of bone marrow-derived mesenchymal stem cells in a photopolymerizing hydrogel. Tissue Eng. 2003; 9:679-688. [PubMed: 13678446]

Woodfield TB, Bezemer JM, Pieper JS, van Blitterswijk CA, Riesle J. Scaffolds for tissue engineering of cartilage. Crit. Rev. Eukaryot. Gene Expr. 2002; 12:209-236. [PubMed: 12449344]

Wozney JM. The bone morphogenetic protein family and osteogenesis. Mol. Reprod. Dev. 1992; 32:160-167. [PubMed: 1637554]

Xu W, Zhang X, Qian H, Zhu W, Sun X, Hu J, Zhou H, Chen Y. Mesenchymal stem cells from adult human bone marrow differentiate into a cardiomyocyte phenotype in vitro. Exp. Biol. Med. (Maywood). 2004; 229:623-631. [PubMed: 15229356]

Ylostalo J, Smith JR, Pochampally RR, Matz R, Sekiya I, Larson BL, Vuoristo JT, Prockop DJ. Use of differentiating adult stem cells (MSCs) to identify new downstream target genes for transcription factors. Stem Cells. 2006

Yoo JU, Barthel TS, Nishimura K, Solchaga L, Caplan AI, Goldberg VM, Johnstone B. The chondrogenic potential of human bone-marrow-derived mesenchymal progenitor cells. J. Bone Joint Surg. Am. 1998; 80:1745-1757. [PubMed: 9875932] 

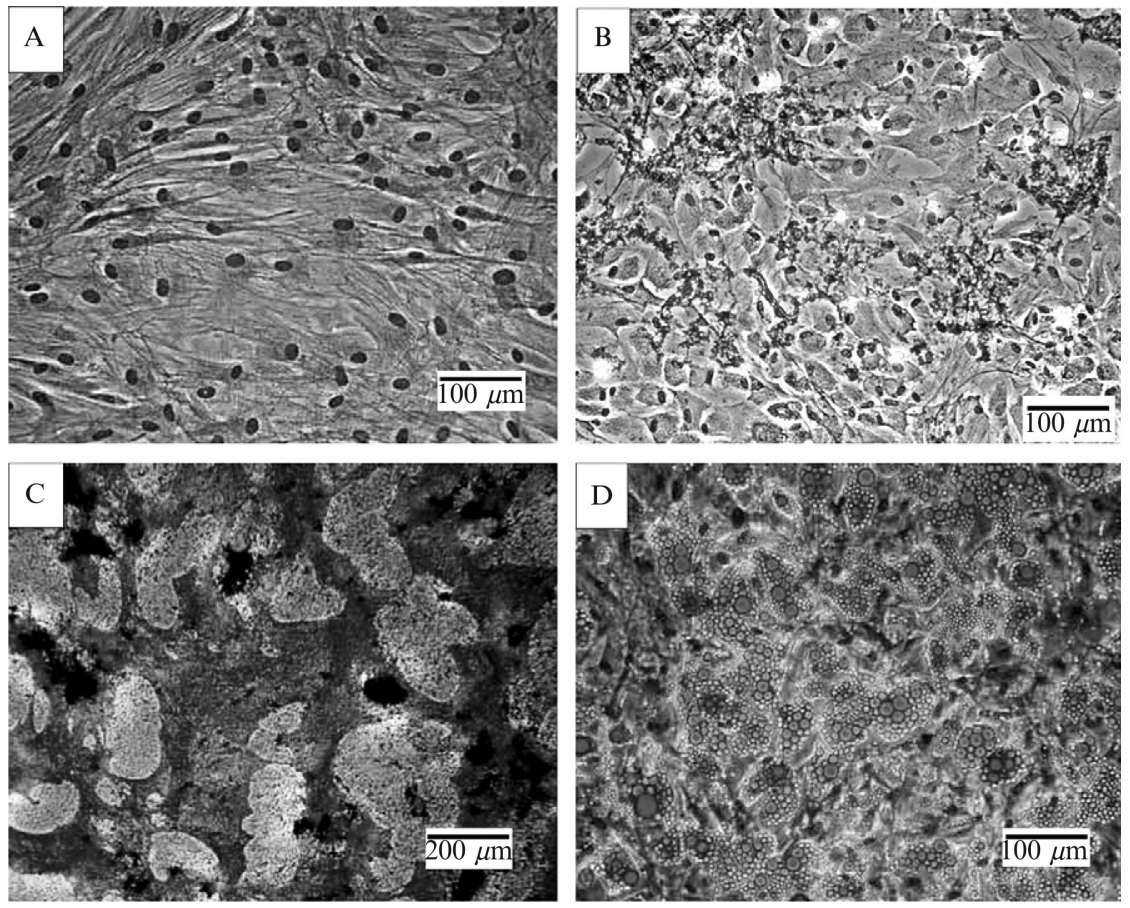

Fig. 1.

(A) Human mesenchymal stem cells (MSCs) isolated from anonymous adult human bone marrow donor after culture expansion (H\&E staining). Further enrichment of MSCs can be accomplished by positive selection using cell surface markers including STRO-1, CD133 (prominin, AC133), p75LNGFR (p75, low-affinity nerve growth factor receptor), CD29, CD44, CD90, CD105, c-kit, SH2 (CD105), SH3, SH4 (CD73), CD71, CD106, CD120a, CD124, and HLA-DR or negative selection (Alhadlaq and Mao, 2004; Lee et al., 2004; Pittenger et al., 1999). (B) Chondrocytes derived from human mesenchymal stem cells showing positive staining to Alcian blue. Additional molecular and genetic markers can be used to further characterize MSC-derived chondrocytes (Alhadlaq and Mao, 2004; Lee et al., 2004; Pittenger et al., 1999). (C) Osteoblasts derived from human mesenchymal stem cells showing positive von Kossa staining for calcium deposition (black) and active alkaline phosphatase enzyme (red). Additional molecular and genetic markers can be used to further characterize MSC-derived chondrocytes (Alhadlaq and Mao, 2004; Lee et al., 2004; Pittenger et al., 1999). (D) Adipocytes derived from human mesenchymal stem cells showing positive Oil Red-O staining of intracellular lipids. Additional molecular and genetic markers can be used to further characterize MSC-derived chondrocytes (Alhadlaq and Mao, 2004; Lee et al., 2004; Pittenger et al., 1999). 


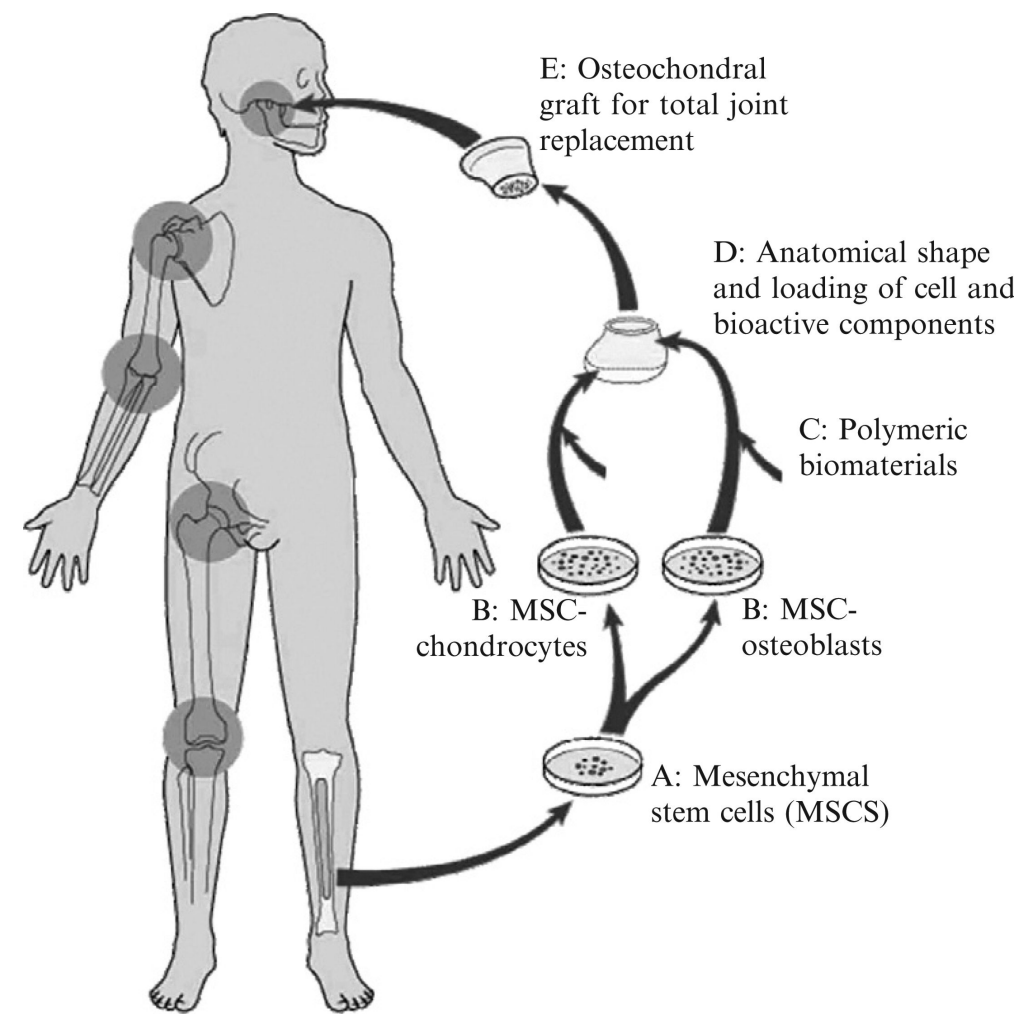

Fig. 2.

Schematic diagram of autologous, MSC-based tissue-engineering therapy for total joint replacement. MSC, mesenchymal stem cells. Progenitor cells such as MSCs are isolated from the bone marrow or other connective sources such as adipose tissue, culture-expanded, and/or differentiated ex vivo toward chondrocytes and osteoblasts. Cells are seeded in biocompatible materials shaped into the anatomical structures of the synovial joint condyle and implanted in vivo. Preliminary proof of concept studies have been reported (Alhadlaq and Mao, 2003, 2005; Alhadlaq et al., 2004; Mao, 2005). 